\title{
Effects of prednisolone in an experimental model of arthritis in the rabbit
}

\author{
B. DAVIS \\ From the Pharmacology Department, Glaxo Research Limited, Fulmer Hall, Fulmer, Bucks
}

Though the aetiology of rheumatoid arthritis remains unknown, it is desirable that any animal model employed in testing drugs for the treatment of this disease should possess some of its pathology including its chronicity. Until recently most models have used isolated facets of the phenomenon of inflammation, such as erythema, oedema, collagen deposition, pyrexia, and pain; such responses usually last a few hours or at most a few days.

Dumonde and Glynn (1962), using an immunological method, produced an arthritis in the rabbit which resembled rheumatoid arthritis. Starting from the hypothesis that rheumatoid arthritis might be an example of an immune disease, they chose several different fibrins as examples of denatured protein which might elicit an autoimmune response. Heterospecific fibrin produced more severe lesions than autologous fibrin and they concluded that this could be due partly to a greater degree of delayed hypersensitivity, and partly to the entire absence of immediate hypersensitivity in autoimmunized animals.

Some exploratory experiments on the effects of

Accepted for publication May 18, 1971. prednisolone in a model of arthritis based on that of Dumonde and Glynn (1962) are described below. Ovalbumin has been chosen as a foreign antigen likely to induce good immediate and delayed hypersensitivity responses.

\section{Methods}

IMMUNIZATION AND CHALLENGE PROCEDURE 28 adult New Zealand white rabbits of either sex (1.9 to $3.6 \mathrm{~kg}$. initial bodyweight) were sensitized by intradermal injection with an emulsion of ovalbumin and Freund's adjuvant into the scruff of the clipped neck. Each rabbit received a total of $1 \mathrm{ml}$. emulsion divided between five sites in the neck. The emulsion was prepared by mixing equal volumes of 3 per cent. ovalbumin (albumin chicken egg $5 \times$ crystallized - Koch Light) in physiological saline, sterilized by Milipore filtration, and $2 \mathrm{mg} . / \mathrm{ml}$. tubercle bacilli (human type, strains C, DT and PN mixed, heat-killed, freeze-dried-supplied by the Ministry of Agriculture, Fisheries and Food, Weybridge, Surrey) suspended in Freund's incomplete adjuvant (Difco). After 28 days each rabbit was challenged with $0.2 \mathrm{ml} .3$ per cent. ovalbumin injected aseptically into the articular space of the right knee through a 23 gauge 1 in. needle inserted from the medial aspect.

Table I Treatment with prednisolone and designation of time of killing

\begin{tabular}{|c|c|c|c|c|c|}
\hline \multirow[t]{2}{*}{ Group } & \multirow{2}{*}{$\begin{array}{l}\text { Treatment with } \\
\text { prednisolone } 1 \mathrm{mg} . / \mathrm{kg} . / \text { day orally }\end{array}$} & \multicolumn{4}{|c|}{ Rabbits designated to be killed at various times after challenge } \\
\hline & & Day 10 & Day 51 & Day 101 & Day 200 \\
\hline $\mathbf{0}$ & Control-No treatment & $\begin{array}{l}130 \\
131\end{array}$ & $\begin{array}{l}132 \\
157\end{array}$ & $\begin{array}{l}134 \\
135\end{array}$ & $\begin{array}{l}136 \\
137 \\
158 \\
159\end{array}$ \\
\hline I & From day of challenge until death & $\begin{array}{l}138 \\
139\end{array}$ & $\begin{array}{l}140 \\
141\end{array}$ & $\begin{array}{l}145 \\
146 \text { (died day 37) }\end{array}$ & $\begin{array}{l}156 \text { (died day } 89 \text { ) } \\
147 \text { (died day } 168 \text { ) }\end{array}$ \\
\hline Ia & From day of challenge to day 100 & & & & $\begin{array}{l}142 \\
143\end{array}$ \\
\hline II & From 51 days after challenge to death & & & $\begin{array}{l}148 \\
149\end{array}$ & $\begin{array}{l}152 \text { (died day 167) } \\
153 \text { (died day 192) }\end{array}$ \\
\hline$\overline{\Pi \mathbf{a}}$ & $\begin{array}{l}\text { From } 51 \text { days after challenge to } \\
\text { day } 100\end{array}$ & & & & $\begin{array}{l}150 \\
151\end{array}$ \\
\hline III & $\begin{array}{l}\text { From } 101 \text { days after challenge to } \\
\text { death }\end{array}$ & & & & $\begin{array}{l}154 \text { (died day } 175) \\
155 \text { (died day } 165 \text { ) }\end{array}$ \\
\hline
\end{tabular}


TREATMENT WITH PREDNISOLONE AND DESIGNATION OF TIME OF KILLING

At the start of the experiment individual animals were allocated to different dosage schedules of prednisolone, and to be killed at various times after challenge. Not all the animals dosed with prednisolone survived to the end of the experiment. The dosing schedules, and the proposed and actual times of death are given in Table I (p. 509).

A $1 \mathrm{mg} . / \mathrm{ml}$. solution of prednisolone was freshly prepared daily by dissolving tablets of prednisolone disodium phosphate (Prednesol-Glaxo) in distilled water. The rabbits were dosed orally by trickling $1 \mathrm{ml} . / \mathrm{kg}$. of this solution over the back of the tongue from a rat oral needle attached to a $5 \mathrm{ml}$. plastic syringe.
MEASUREMENT OF KNEE DIAMETER

The medial to lateral diameters of the right and left knees were measured at the level of the articular space using an engineer's micrometer, before and at various ? times after challenge. The ratio of the right (challenged) $\equiv$ to left (unchallenged) knee diameter for each rabbit was $s$ determined at these times (Table II).

EXAMINATION OF THE KNEE JOINTS AT DEATH When rabbits were killed with an intravenous overdose of pentobarbitone sodium, or died, the knees were swabbed ${ }^{\circ}$ with 1 per cent. cetrimide and opened aseptically by $\vec{\circ}$ cutting the quadriceps tendon and turning it forward. An aerobic culture of the challenged joint contents was made $\vec{\omega}$

Table II Ratios of right (challenged) to left (unchallenged) knee diameters at various times before, during, and

\begin{tabular}{|c|c|c|c|c|c|c|c|c|c|c|}
\hline \multirow[t]{2}{*}{ Group } & \multirow{2}{*}{$\begin{array}{l}\text { Period of dosage of } \\
\text { prednisolone } \\
(1 \mathrm{mg} . / \mathrm{kg} . / \text { day orally) } \\
(\text { days })\end{array}$} & \multirow{2}{*}{$\begin{array}{l}\text { Mode of } \\
\text { death }\end{array}$} & \multirow{2}{*}{$\begin{array}{l}\text { Time of } \\
\text { death } \\
\text { after challenge } \\
\text { (days) }\end{array}$} & \multirow{2}{*}{$\begin{array}{l}\text { Animal } \\
\text { code } \\
\text { number }\end{array}$} & \multicolumn{6}{|c|}{ Day of measurement of joint ratios } \\
\hline & & & & & -4 & +1 & 2 & 3 & 4 & 7 \\
\hline \multirow[t]{2}{*}{$\mathbf{0}$} & $\begin{array}{l}\text { None } \\
\text { (Control group) }\end{array}$ & $\begin{array}{l}\text { Killed } \\
\text { Killed } \\
\text { Killed } \\
\text { Killed } \\
\text { Killed } \\
\text { Killed } \\
\text { Killed } \\
\text { Killed } \\
\text { Killed } \\
\text { Killed }\end{array}$ & $\begin{array}{l}10 \\
10 \\
51 \\
51 \\
101 \\
101 \\
200 \\
200 \\
200 \\
200\end{array}$ & $\begin{array}{l}130 \\
131 \\
132 \\
157 \\
134 \\
135 \\
136 \\
137 \\
158 \\
159\end{array}$ & $\begin{array}{l}0.98 \\
0.98 \\
0.98 \\
1.00 \\
0.98 \\
0.98 \\
0.99 \\
0.98 \\
0.93 \\
0.96\end{array}$ & $\begin{array}{l}1 \cdot 17 \\
1 \cdot 14 \\
1 \cdot 15 \\
1 \cdot 21 \\
1 \cdot 14 \\
1 \cdot 18 \\
1 \cdot 12 \\
1 \cdot 17 \\
1 \cdot 24 \\
1 \cdot 26\end{array}$ & $\begin{array}{l}1 \cdot 20 \\
1 \cdot 23 \\
1 \cdot 22 \\
1 \cdot 29 \\
1 \cdot 36 \\
1 \cdot 23 \\
1 \cdot 22 \\
1 \cdot 22 \\
1 \cdot 20 \\
1 \cdot 36\end{array}$ & $\begin{array}{l}1 \cdot 25 \\
1 \cdot 26 \\
1 \cdot 26 \\
1 \cdot 36 \\
1 \cdot 38 \\
1 \cdot 23 \\
1 \cdot 23 \\
1 \cdot 19 \\
1 \cdot 23 \\
1 \cdot 26\end{array}$ & $\begin{array}{l}1 \cdot 29 \\
1 \cdot 28 \\
1 \cdot 32 \\
1 \cdot 31 \\
1 \cdot 29 \\
1 \cdot 22 \\
1 \cdot 20 \\
1 \cdot 17 \\
1 \cdot 17 \\
1 \cdot 38\end{array}$ & $\begin{array}{l}1 \cdot 28 \\
1 \cdot 21 \\
1 \cdot 25 \\
1 \cdot 39 \\
1 \cdot 25 \\
1 \cdot 34 \\
1 \cdot 150 \\
1 \cdot 230 \\
1 \cdot 22 \leq \\
1 \cdot 460\end{array}$ \\
\hline & & & & Means & 0.98 & $1 \cdot 18$ & $1 \cdot 25$ & $1 \cdot 27$ & $1 \cdot 26$ & $1 \cdot 28$ \\
\hline \multirow[t]{2}{*}{$\mathbf{I}$} & $\begin{array}{l}0 \text { to } 10 \\
0 \text { to } 10 \\
0 \text { to } 36 \\
0 \text { to } 50 \\
0 \text { to } 50 \\
0 \text { to } 89 \\
0 \text { to } 100 \\
0 \text { to } 167\end{array}$ & $\begin{array}{l}\text { Killed } \\
\text { Killed } \\
\text { Died } \\
\text { Killed } \\
\text { Killed } \\
\text { Died } \\
\text { Killed } \\
\text { Died }\end{array}$ & $\begin{array}{r}10 \\
10 \\
37 \\
51 \\
51 \\
89 \\
101 \\
167\end{array}$ & $\begin{array}{l}138 \\
139 \\
146 \\
140 \\
141 \\
156 \\
145 \\
147\end{array}$ & $\begin{array}{l}0.95 \\
0.97 \\
1.00 \\
0.98 \\
0.98 \\
1.01 \\
0.97 \\
0.95\end{array}$ & $\begin{array}{l}1 \cdot 12 \\
1 \cdot 14 \\
1 \cdot 14 \\
1 \cdot 16 \\
1 \cdot 38 \\
1 \cdot 20 \\
1 \cdot 14 \\
1 \cdot 12\end{array}$ & $\begin{array}{l}1 \cdot 23 \\
1 \cdot 18 \\
1 \cdot 15 \\
1 \cdot 24 \\
1 \cdot 32 \\
1 \cdot 12 \\
1 \cdot 16 \\
1 \cdot 12\end{array}$ & $\begin{array}{l}1 \cdot 12 \\
1 \cdot 12 \\
1 \cdot 13 \\
1 \cdot 16 \\
1 \cdot 26 \\
1.07 \\
1 \cdot 17 \\
1.06\end{array}$ & $\begin{array}{l}1.05 \\
1.07 \\
1.09 \\
1 \cdot 14 \\
1.23 \\
1 \cdot 10 \\
1 \cdot 12 \\
1 \cdot 10\end{array}$ & $\begin{array}{l}1.00 \\
1.02 \\
1.04 \\
1.04 \\
1.14 \\
1.06 \\
1.09 \\
1.01\end{array}$ \\
\hline & & & & Means & 0.98 & $1 \cdot 18$ & $1 \cdot 19$ & $1 \cdot 14$ & $1 \cdot 11$ & $1 \cdot 05$ \\
\hline \multirow[t]{2}{*}{ Ia } & $\begin{array}{l}0 \text { to } 100 \\
0 \text { to } 100\end{array}$ & $\begin{array}{l}\text { Killed } \\
\text { Killed }\end{array}$ & $\begin{array}{l}200 \\
200\end{array}$ & $\begin{array}{l}142 \\
143\end{array}$ & $\begin{array}{l}0.98 \\
0.97\end{array}$ & $\begin{array}{l}1 \cdot 16 \\
1 \cdot 12\end{array}$ & $\begin{array}{l}1 \cdot 21 \\
1 \cdot 14\end{array}$ & $\begin{array}{l}1 \cdot 13 \\
1 \cdot 11\end{array}$ & $\begin{array}{l}1.04 \\
1.06\end{array}$ & $\begin{array}{l}1.05 \\
1.01\end{array}$ \\
\hline & & & & Means & 0.98 & $1 \cdot 14$ & $1 \cdot 18$ & $1 \cdot 12$ & $1 \cdot 05$ & $1 \cdot 03$ \\
\hline \multirow[t]{2}{*}{ II } & $\begin{array}{l}51 \text { to } 100 \\
51 \text { to } 100 \\
51 \text { to } 167 \\
51 \text { to } 191\end{array}$ & $\begin{array}{l}\text { Killed } \\
\text { Killed } \\
\text { Died } \\
\text { Died }\end{array}$ & $\begin{array}{l}101 \\
101 \\
167 \\
192\end{array}$ & $\begin{array}{l}148 \\
149 \\
152 \\
153\end{array}$ & $\begin{array}{l}0.97 \\
0.99 \\
0.98 \\
0.99\end{array}$ & $\begin{array}{l}1 \cdot 14 \\
1 \cdot 18 \\
1 \cdot 23 \\
1 \cdot 22\end{array}$ & $\begin{array}{l}1 \cdot 23 \\
1 \cdot 25 \\
1 \cdot 33 \\
1 \cdot 34\end{array}$ & $\begin{array}{l}1 \cdot 21 \\
1 \cdot 25 \\
1 \cdot 28 \\
1 \cdot 30\end{array}$ & $\begin{array}{l}1 \cdot 20 \\
1 \cdot 28 \\
1 \cdot 28 \\
1 \cdot 33\end{array}$ & $\begin{array}{l}1 \cdot 24 \\
1 \cdot 31 \\
1 \cdot 37 \\
1 \cdot 27\end{array}$ \\
\hline & & & & Means & 0.98 & $1 \cdot 19$ & $1 \cdot 29$ & $1 \cdot 26$ & $1 \cdot 27$ & $1 \cdot 30$ \\
\hline \multirow[t]{2}{*}{ IIa } & $\begin{array}{l}51 \text { to } 100 \\
51 \text { to } 100\end{array}$ & $\begin{array}{l}\text { Killed } \\
\text { Killed }\end{array}$ & $\begin{array}{l}200 \\
200\end{array}$ & $\begin{array}{l}150 \\
151\end{array}$ & $\begin{array}{l}1.00 \\
0.99\end{array}$ & $\begin{array}{l}1 \cdot 21 \\
1 \cdot 15\end{array}$ & $\begin{array}{l}1 \cdot 35 \\
1 \cdot 22\end{array}$ & $\begin{array}{l}1 \cdot 35 \\
1 \cdot 20\end{array}$ & $\begin{array}{l}1 \cdot 36 \\
1 \cdot 22\end{array}$ & $\begin{array}{l}1 \cdot 32 \\
1 \cdot 13\end{array}$ \\
\hline & & & & Means & $1 \cdot 00$ & $1 \cdot 18$ & $1 \cdot 29$ & $1 \cdot 28$ & $1 \cdot 29$ & $1 \cdot 23$ \\
\hline \multirow[t]{2}{*}{ III } & $\begin{array}{l}101 \text { to } 164 \\
101 \text { to } 174\end{array}$ & $\begin{array}{l}\text { Died } \\
\text { Died }\end{array}$ & $\begin{array}{l}165 \\
175\end{array}$ & $\begin{array}{l}155 \\
154\end{array}$ & $\begin{array}{l}0.97 \\
0.99\end{array}$ & $\begin{array}{l}1 \cdot 17 \\
1 \cdot 10\end{array}$ & $\begin{array}{l}1 \cdot 29 \\
1 \cdot 14\end{array}$ & $\begin{array}{l}1 \cdot 24 \\
1 \cdot 17\end{array}$ & $\begin{array}{l}1 \cdot 25 \\
1 \cdot 22\end{array}$ & $\begin{array}{l}1 \cdot 26 \\
1 \cdot 26\end{array}$ \\
\hline & & & & Means & 0.98 & $1 \cdot 14$ & $1 \cdot 22$ & $1 \cdot 21$ & $1 \cdot 24$ & $1 \cdot 26$ \\
\hline
\end{tabular}


on blood agar and smears of the joint fluid prepared. Two smears were made, dried, fixed with methyl alcohol, and stained; one with Leishman's stain, and the other with Harris's haematoxylin and eosin. In some cases wet films were prepared and stained vitally with SternheimerMalbin stain (crystal violet 0.1 per cent., safranin 0.2 per cent., alcohol 10 per cent.). The internal macroscopic appearance of both the right and left knee joints was recorded. The joints were fixed in buffered formol saline and then decalcified with Kristensen's fluid. When sufficiently decalcified the joints were divided in the sagittal plane and preserved in 70 per cent. alcohol. The medial half of each joint was sectioned, stained with haematoxylin and eosin, and examined histologically.

\section{Results}

No infection was detected in any of the challenged joints.

Group $\mathrm{O}-\mathrm{Control}$ rabbits which received no prednisolone

EXTERNAL APPEARANCE One day after challenge the injected knees were swollen and turgid and the skin around was red and warm. The swellings reached a first maximum between the 3rd and 7th day, then partially declined with a loss of redness

after different dose regimens of prednisolone

(challenged on day 0. )

\begin{tabular}{|c|c|c|c|c|c|c|c|c|c|c|c|c|c|c|c|c|}
\hline 10 & 14 & 21 & 35 & 50 & 57 & 71 & 85 & 99 & 106 & 113 & 134 & 148 & 162 & 176 & 190 & 197 \\
\hline $\begin{array}{l}1 \cdot 22 \\
1 \cdot 13 \\
1 \cdot 22 \\
1 \cdot 30 \\
1 \cdot 18 \\
1 \cdot 19 \\
1 \cdot 12 \\
1 \cdot 11 \\
1 \cdot 12 \\
1 \cdot 36\end{array}$ & $\begin{array}{l}1 \cdot 22 \\
1 \cdot 32 \\
1 \cdot 09 \\
1 \cdot 21 \\
1 \cdot 09 \\
1 \cdot 08 \\
1 \cdot 10 \\
1 \cdot 24\end{array}$ & $\begin{array}{l}1 \cdot 29 \\
1.36 \\
1.06 \\
1.20 \\
1.09 \\
1.08 \\
1.12 \\
1.26\end{array}$ & $\begin{array}{l}1 \cdot 38 \\
1 \cdot 29 \\
1 \cdot 08 \\
1 \cdot 14 \\
1 \cdot 06 \\
1 \cdot 07 \\
1 \cdot 08 \\
1 \cdot 32\end{array}$ & $\begin{array}{l}1 \cdot 28 \\
1 \cdot 27 \\
1 \cdot 04 \\
1 \cdot 13 \\
1 \cdot 10 \\
1 \cdot 11 \\
1 \cdot 17 \\
1 \cdot 23\end{array}$ & $\begin{array}{l}1 \cdot 10 \\
1 \cdot 14 \\
1 \cdot 11 \\
1 \cdot 11 \\
1 \cdot 16 \\
1 \cdot 23\end{array}$ & $\begin{array}{l}1 \cdot 06 \\
1 \cdot 18 \\
1 \cdot 14 \\
1 \cdot 09 \\
1 \cdot 25 \\
1 \cdot 28\end{array}$ & $\begin{array}{l}1.05 \\
1 \cdot 16 \\
1 \cdot 12 \\
1.07 \\
1.22 \\
1.34\end{array}$ & $\begin{array}{l}1 \cdot 08 \\
1 \cdot 18 \\
1 \cdot 20 \\
1 \cdot 16 \\
1 \cdot 16 \\
1 \cdot 33\end{array}$ & $\begin{array}{l}1 \cdot 16 \\
1 \cdot 11 \\
1 \cdot 19 \\
1 \cdot 36\end{array}$ & $\begin{array}{l}1 \cdot 22 \\
1 \cdot 20 \\
1 \cdot 15 \\
1 \cdot 39\end{array}$ & $\begin{array}{l}1 \cdot 29 \\
1 \cdot 27 \\
1 \cdot 23 \\
1 \cdot 38\end{array}$ & $\begin{array}{l}1 \cdot 22 \\
1 \cdot 29 \\
1 \cdot 13 \\
1 \cdot 47\end{array}$ & $\begin{array}{l}1 \cdot 27 \\
1 \cdot 39 \\
1 \cdot 15 \\
1 \cdot 43\end{array}$ & $\begin{array}{l}1 \cdot 29 \\
1 \cdot 30 \\
1 \cdot 13 \\
1 \cdot 31\end{array}$ & $\begin{array}{l}1 \cdot 26 \\
1 \cdot 30 \\
1 \cdot 06 \\
1 \cdot 39\end{array}$ & $\begin{array}{l}1 \cdot 27 \\
1 \cdot 31 \\
1 \cdot 14 \\
1 \cdot 39\end{array}$ \\
\hline $1 \cdot 20$ & $1 \cdot 17$ & $1 \cdot 18$ & $1 \cdot 18$ & $1 \cdot 17$ & $1 \cdot 14$ & $1 \cdot 17$ & $1 \cdot 16$ & $1 \cdot 19$ & $1 \cdot 21$ & $1 \cdot 24$ & $1 \cdot 29$ & $\overline{1 \cdot 28}$ & $\overline{1 \cdot 31}$ & $1 \cdot 26$ & $1 \cdot 25$ & $1 \cdot 28$ \\
\hline $\begin{array}{l}1.00 \\
1.01 \\
1.01 \\
1.04 \\
1.07 \\
1.03 \\
1.05 \\
0.98\end{array}$ & $\begin{array}{l}1.00 \\
1.00 \\
1.04 \\
1.04 \\
1.04 \\
1.00\end{array}$ & $\begin{array}{l}0.98 \\
0.99 \\
1.02 \\
1.02 \\
1.03 \\
0.99\end{array}$ & $\begin{array}{l}0.99 \\
1.01 \\
0.99 \\
1.05 \\
1.06 \\
0.98\end{array}$ & $\begin{array}{l}0.99 \\
1.00 \\
1.01 \\
1.09 \\
0.99\end{array}$ & $\begin{array}{l}1.03 \\
1.03 \\
1.00\end{array}$ & $\begin{array}{l}1.03 \\
1.07 \\
0.99\end{array}$ & $\begin{array}{l}1.06 \\
1.12 \\
0.96\end{array}$ & $\begin{array}{l}1.10 \\
0.96\end{array}$ & 0.98 & 0.98 & 0.98 & $1 \cdot 02$ & 0.98 & & & \\
\hline $1 \cdot 02$ & $1 \cdot 02$ & $1 \cdot 01$ & 1.01 & $1 \cdot 02$ & 1.02 & 1.03 & 1.05 & 1.03 & 0.98 & 0.98 & 0.98 & $1 \cdot 02$ & 0.98 & & & \\
\hline $\begin{array}{l}1.00 \\
0.97\end{array}$ & $\begin{array}{l}1.02 \\
1.00\end{array}$ & $\begin{array}{l}0.97 \\
0.99\end{array}$ & $\begin{array}{l}\overline{1.00} \\
0.97\end{array}$ & $\begin{array}{l}0.98 \\
0.98\end{array}$ & $\begin{array}{l}0.98 \\
0.96\end{array}$ & $\begin{array}{l}0.98 \\
0.99\end{array}$ & $\begin{array}{l}0.99 \\
1.11\end{array}$ & $\begin{array}{l}1.00 \\
0.98\end{array}$ & $\begin{array}{l}0.99 \\
0.98\end{array}$ & $\begin{array}{l}1.01 \\
1.06\end{array}$ & $\begin{array}{l}\overline{1.08} \\
1 \cdot 12\end{array}$ & $\begin{array}{l}\overline{1.04} \\
1 \cdot 11\end{array}$ & $\begin{array}{l}1.08 \\
1.09\end{array}$ & $\begin{array}{l}1.03 \\
1 \cdot 11\end{array}$ & $\begin{array}{l}1.03 \\
1.09\end{array}$ & $\begin{array}{l}1 \cdot 01 \\
1 \cdot 10\end{array}$ \\
\hline 0.99 & 1.01 & 0.98 & 0.99 & 0.98 & 0.97 & 0.99 & 1.05 & 0.99 & 0.99 & $\overline{1.04}$ & $\overline{1 \cdot 10}$ & $\overline{1.08}$ & $\overline{1.09}$ & $\overline{1.07}$ & $\overline{1.06}$ & 1.06 \\
\hline $\begin{array}{l}1 \cdot 10 \\
1.41 \\
1 \cdot 36 \\
1 \cdot 25\end{array}$ & $\begin{array}{l}1.09 \\
1.43 \\
1.41 \\
1.20\end{array}$ & $\begin{array}{l}\overline{1 \cdot 12} \\
1.51 \\
1 \cdot 36 \\
1 \cdot 19\end{array}$ & $\begin{array}{l}\overline{1 \cdot 07} \\
1 \cdot 39 \\
1 \cdot 40 \\
1 \cdot 34\end{array}$ & $\begin{array}{l}\overline{1 \cdot 11} \\
1 \cdot 27 \\
1 \cdot 38 \\
1 \cdot 38\end{array}$ & $\begin{array}{l}1.07 \\
1.28 \\
1.33 \\
1.26\end{array}$ & $\begin{array}{l}1.05 \\
1.22 \\
1 \cdot 25 \\
1 \cdot 19\end{array}$ & $\begin{array}{l}\overline{1 \cdot 08} \\
1 \cdot 28 \\
1 \cdot 35 \\
1 \cdot 17\end{array}$ & $\begin{array}{l}\overline{1.04} \\
1 \cdot 24 \\
1 \cdot 28 \\
1 \cdot 15\end{array}$ & $\begin{array}{l}1 \cdot 27 \\
1 \cdot 17\end{array}$ & $\begin{array}{l}1 \cdot 35 \\
1 \cdot 17\end{array}$ & $\begin{array}{l}1 \cdot 38 \\
1 \cdot 19\end{array}$ & $\begin{array}{l}1 \cdot 38 \\
1 \cdot 13\end{array}$ & $\begin{array}{l}1 \cdot 35 \\
1 \cdot 17\end{array}$ & $1 \cdot 19$ & $1 \cdot 16$ & \\
\hline $1 \cdot 28$ & $\overline{1 \cdot 28}$ & $1 \cdot 30$ & $\overline{1 \cdot 30}$ & $1 \cdot 29$ & $1 \cdot 24$ & $1 \cdot 18$ & $1 \cdot 22$ & $1 \cdot 18$ & $1 \cdot 22$ & $1 \cdot 26$ & $1 \cdot 29$ & $1 \cdot 26$ & $1 \cdot 26$ & $1 \cdot 19$ & $1 \cdot 16$ & \\
\hline $\begin{array}{l}1 \cdot 34 \\
1 \cdot 15\end{array}$ & $\begin{array}{l}1 \cdot 25 \\
1 \cdot 11\end{array}$ & $\begin{array}{l}1.24 \\
1.06\end{array}$ & $\begin{array}{l}1 \cdot 15 \\
1.07\end{array}$ & $\begin{array}{l}1 \cdot 16 \\
1 \cdot 09\end{array}$ & $\begin{array}{l}1.07 \\
1.07\end{array}$ & $\begin{array}{l}1.14 \\
1.06\end{array}$ & $\begin{array}{l}1.23 \\
1.05\end{array}$ & $\begin{array}{l}1.09 \\
1.01\end{array}$ & $\begin{array}{l}1.20 \\
1.06\end{array}$ & $\begin{array}{l}1 \cdot 29 \\
1 \cdot 12\end{array}$ & $\begin{array}{l}1 \cdot 26 \\
1 \cdot 32\end{array}$ & $\begin{array}{l}1 \cdot 28 \\
1 \cdot 24\end{array}$ & $\begin{array}{l}\overline{1 \cdot 28} \\
1 \cdot 25\end{array}$ & $\begin{array}{l}\overline{1 \cdot 30} \\
1 \cdot 31\end{array}$ & $\begin{array}{l}\overline{1 \cdot 35} \\
1 \cdot 30\end{array}$ & \\
\hline $1 \cdot 25$ & $1 \cdot 18$ & $1 \cdot 15$ & $1 \cdot 11$ & $1 \cdot 13$ & $1 \cdot 07$ & $1 \cdot 10$ & $1 \cdot 14$ & 1.05 & $1 \cdot 13$ & $\overline{1 \cdot 21}$ & $1 \cdot 29$ & $1 \cdot 26$ & $1 \cdot 27$ & $1 \cdot 31$ & $\overline{1 \cdot 33}$ & $1 \cdot 33$ \\
\hline $\begin{array}{l}1 \cdot 22 \\
1 \cdot 24\end{array}$ & $\begin{array}{l}1.23 \\
1.27\end{array}$ & $\begin{array}{l}1 \cdot 15 \\
1 \cdot 27\end{array}$ & $\begin{array}{l}\overline{1 \cdot 12} \\
1 \cdot 32\end{array}$ & $\begin{array}{l}\overline{1 \cdot 15} \\
1.40\end{array}$ & $\begin{array}{l}\overline{1 \cdot 13} \\
1 \cdot 28\end{array}$ & $\begin{array}{l}1 \cdot 14 \\
1 \cdot 36\end{array}$ & $\begin{array}{l}1 \cdot 17 \\
1 \cdot 38\end{array}$ & $\begin{array}{l}1 \cdot 15 \\
1 \cdot 38\end{array}$ & $\begin{array}{l}1 \cdot 18 \\
1 \cdot 38\end{array}$ & $\begin{array}{l}1 \cdot 14 \\
1 \cdot 33\end{array}$ & $\begin{array}{l}\overline{1 \cdot 12} \\
1 \cdot 34\end{array}$ & $\begin{array}{l}1 \cdot 13 \\
1 \cdot 30\end{array}$ & $\begin{array}{l}1 \cdot 18 \\
1 \cdot 33\end{array}$ & & & \\
\hline 23 & $1 \cdot 25$ & $1 \cdot 21$ & $\cdot 22$ & $\overline{1.28}$ & $\overline{1 \cdot 21}$ & $\overline{1 \cdot 25}$ & $1 \cdot 28$ & $1 \cdot 27$ & $\overline{1 \cdot 28}$ & $1 \cdot 24$ & $1 \cdot 23$ & $1 \cdot 22$ & $1 \cdot 26$ & & & \\
\hline
\end{tabular}


and warmth. Approximately $\mathbf{7 0}$ days after challenge the swellings of the injected knees began to increase and reached a second maximum at about 160 days (Fig. 1; Table II). These secondary swellings, which were still present when the animals were killed, differed from those seen initially in that they were hard and incompressible and the epiphyses appeared enlarged. Crepitation was often detected on flexing the knee, and although occasionally the patella was displaced medially, the rabbits showed a surprising indifference to their swollen knees being manipulated.

INTERNAL APPEARANCE The biphasic nature of the response was less evident on internal examination of the joints. A thick cloudy exudate, often in copious amounts, was present in the injected joints at all stages of the reaction, and the synovium was superficially proliferated. Erosions of the articular cartilage were first seen in the animals killed 51 days after challenge and became more extensive the longer the reaction proceeded.

Microscopically, the joint exudate was of almost constant cellular composition throughout the 200 days of the experiment. Many cells were present; about half were polymorphonuclear leucocytes (many degenerate) and the rest were composed of equal numbers of small lymphocytes and macrophages plus occasional synovial cells. The macrophages often contained one or more ingested polymorph, but their most striking feature was the presence of small colourless vacuoles in the cytoplasm when stained by Leishman or haematoxylin and eosin (Fig. 2). The vacuoles were small in number and incidence at the beginning but became

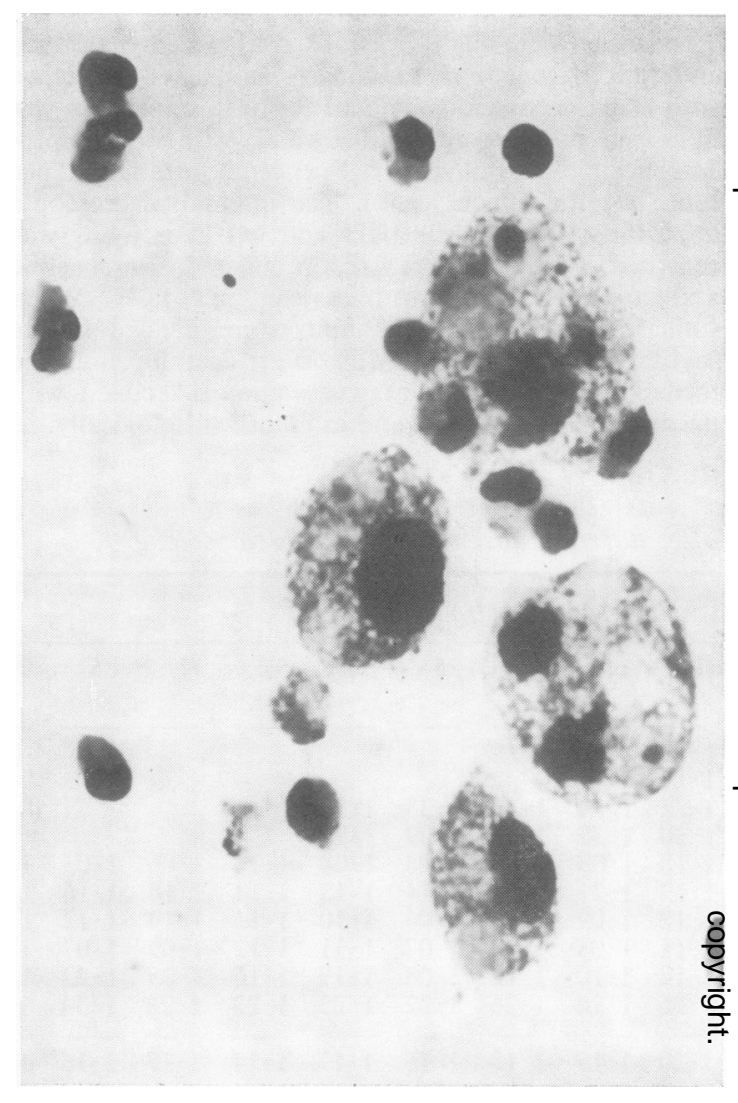

IG. 2 Synovial exudate from rabbit 136 (Group 0 -no treatment) killed 200 days after challenge. Each macrophage contains two to five faintly stained polymorphonuclear leucocytes in various stages of digestion as well as many small colourless vacuoles. Leishman. $\times 1,000$

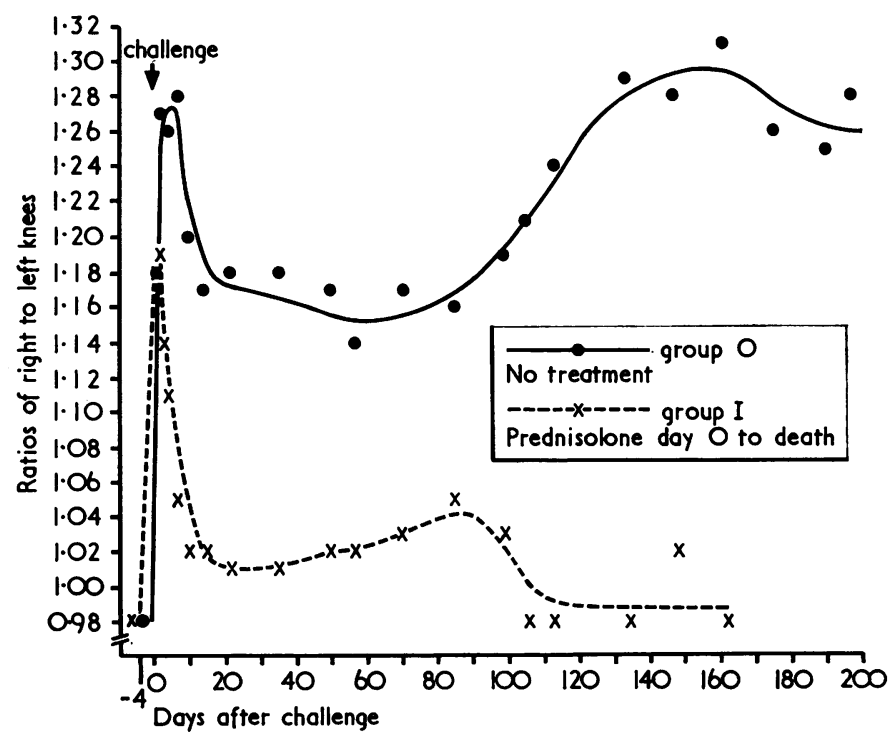

FIG. 1. Ratio of right (challenged) to left (unchallenged) knee diameters in Group 0-no treatment, and Group I- O prednisolone $1 \mathrm{mg} . / \mathrm{kg}$. daily from day of challenge (day 0$)$ to death. 
more numerous as the reaction developed. When examined in the wet films stained with SternheimerMalbin, the macrophages stood out as large cells with mauve nuclei surrounded by as many as 20 to 100 small, discrete, spherical, grey-green, homogeneous inclusions displaced by an occasional indistinct area (presumably an ingested polymorph) It was not necessary to stain the cells or to use high magnification to detect them in wet films. At low magnification and with reduced lighting, the macrophages containing the small inclusions stood out sharply as cells filled with brown specks. No comparable inclusion bodies were seen in the polymorphs or lymphocytes.

Histologically, the initial reaction in the joints began as an acute inflammatory response of the synovium which gradually became chronic and persisted throughout the entire period of the experiment. The other joint lesions appeared later and were probably reflected in the secondary swellings. The synovium was highly vascularized 10 days after challenge with an increase of fibroblasts and lining cells, and pockets of lymphoid cells. Masses of lymphoid and plasma cells lined the surface of the synovium and there were areas of fibrinoid deposit in the articular space. This reaction was accompanied by pannus formation at the junction of the synovium with the bone, and the bone was being invaded. Though the pannus persisted it did not become very extensive and did not appear to be responsible for all the subsequent changes in the articular cartilage. The menisci were being replaced from their bases by inflammatory tissue.

By 51 days after challenge synovial tissue was greatly increased and contained fibroblasts and dense areas of lymphocytes and plasma cells. The surface of the synovium was formed into long highly vascularized villi. These villi almost filled the articular space and were interspersed with fibrinoid deposits. The infiltration of the menisci by fibroblasts continued and their free edges were becoming fibrillated. The articular cartilage showed some undulation of the surface or severe fibrillation, and loss of cellular elements at sites distant from the invading pannus.

These effects were all present at 101 days but had become more pronounced with complete loss of the articular cartilage in some areas leaving bare bone.

By 200 days after challenge the masses of greatly contorted vascular synovial villi were packed with layers of fibroblasts, lymphoid, and plasma cells, as in rabbit 137 (Fig. 4, overleaf). The villi were also coated with hyperplastic lining cells with similarities to the vacuolated macrophages of the synovial exudate. The synovial pannus showed little sign of extension at the junction with the articular cartilage but was eroding the bone (Fig. 5 , overleaf). In rabbit

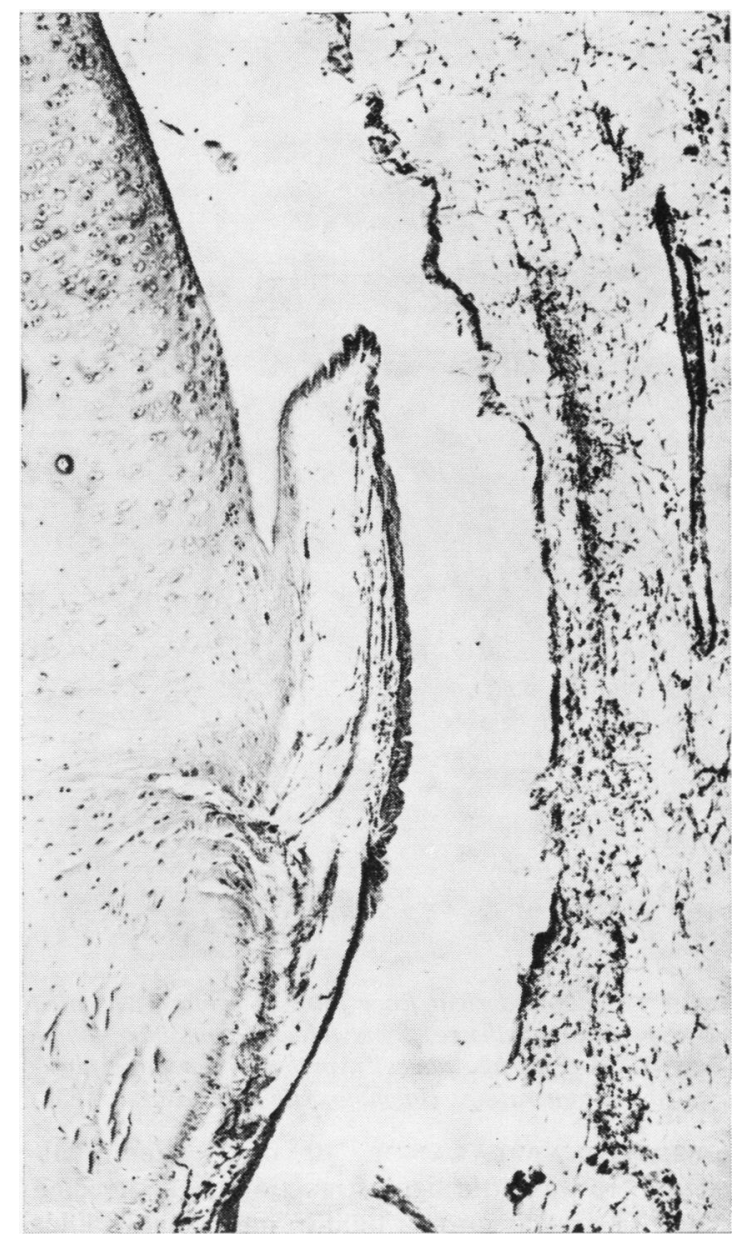

FIG. 3 Unchallenged left knee joint of rabbit 137 (Group 0 - no treatment) killed 200 days after challenge of right knee. Junction of articular cartilage with synovium for comparison with challenged joints. Haematoxylin and eosin. $\times 75$

159 the synovial reaction had declined but the menisci were formed into processes of cartilaginous metaplasia. The articular cartilage was either degenerating with chondrocytes formed in clumps, fibrillated, or completely absent.

Group I-Rabbits dosed daily with prednisolone from the day of challenge until death

EXTERNAL APPEARANCE One day after challenge the injected knees of this group were similar in appearance to those of the rabbits given no prednisolone (Group 0). The swellings reached or had passed their peak by the 2nd day and then declined progressively until by about the 10th day, and subsequently the injected joints were usually indistinguishable, superficially, from the uninjected joints (Fig. 1; Table II). 


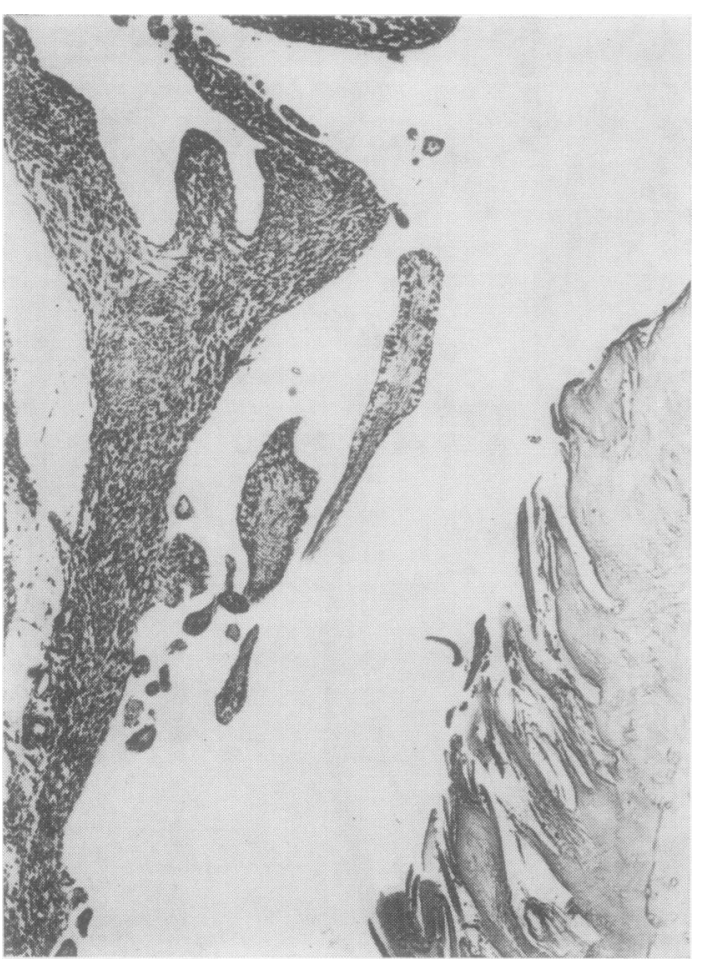

FIG. 4 Challenged right knee joint of rabbit 137 killed 200 days after challenge. Synovial villi containing fibroblasts and foci of plasma cells, articular cartilage fibrillated and degenerating. Haematoxylin and eosin. $\times 63$

INTERNAL APPEARANCE 10 days after challenge there was little sign of reaction in the injected joints. There was normal fluid in one animal's joint (138), whilst that of the other (139) contained a little thick orange exudate. This exudate contained many cells, mostly polymorphs, with small lymphocytes, macrophages occasionally containing ingested polymorphs and colourless vacuoles, and a few synovial cells. The synovial membranes of both animals were slightly red but no other abnormalities were seen. Histologically, the synovial tissue was composed of normal fat cells and was vascularized with some fibroblasts and round cells at the surface and a little fibrinoid deposit. The articular cartilage was normal except for slight pannus at the edge. The joints of the rabbits killed at 51 days appeared normal, though there were a few polymorphs in addition to synovial cells in the joint fluid of rabbit 141 . In this rabbit the synovial tissue was slightly hypertrophied with fibroblasts and round cells, a little fibrinoid deposit in one area, and slight pannus at the edge of the articular cartilage. The joint of the rabbit which died at 37 days appeared completely normal.

The single rabbit (145) killed at 101 days had a moderate amount of thick viscous fluid in the injected joint, the synovial tissue was proliferated,

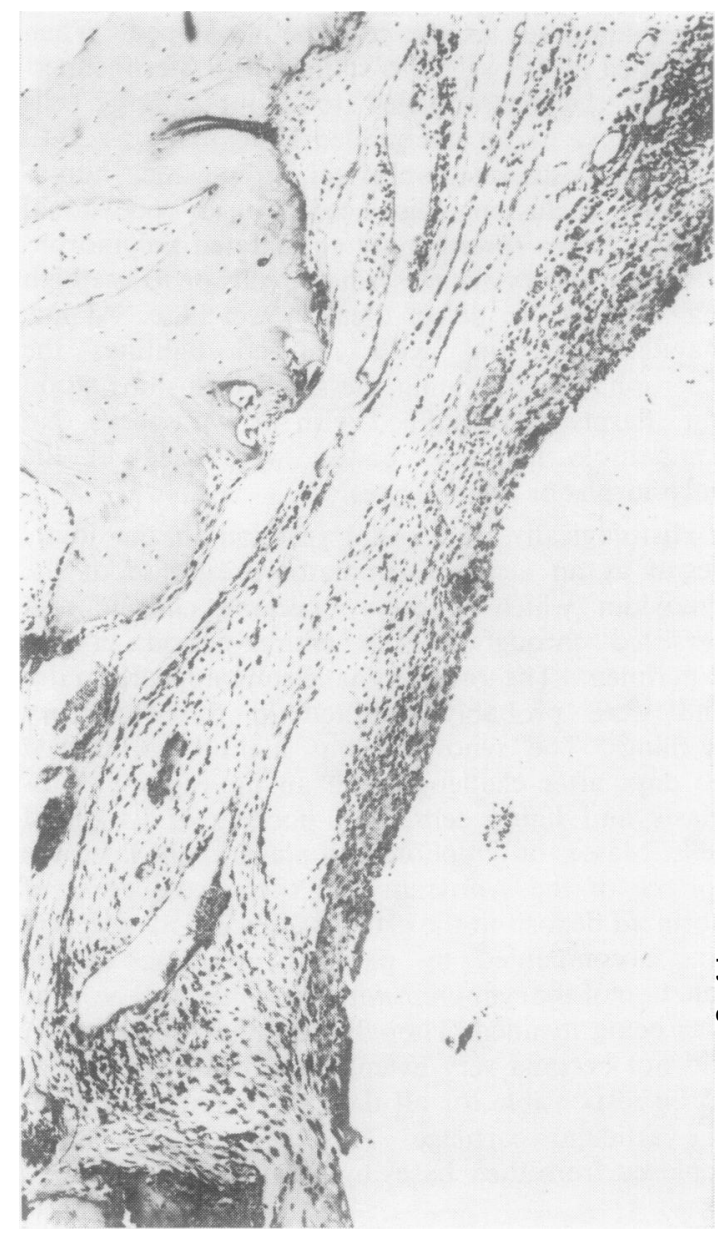

FIG. 5 Challenged right knee joint of rabbit 137 killed 200 days after challenge. Active synovial pannus displacing articular cartilage at junction with synovium and eroding bone. Haematoxylin and eosin. $\times 75$

and there was a slight indication of erosion of the femoral condyles. The exudate was similar in all respects to that seen in animals of Group 0 . The synovial tissue was composed mostly of normal fat cells with some fibroblasts, and discrete areas of lymphoid and plasma cells. There was some fibrinoid deposit but no synovial villi. The menisci were only normal towards their tips, the bases being invaded by fibrous tissue (Fig. 6). Some parts of the articular cartilage were devoid of cells and degenerating with slight fibrillation. There was a small area of pannus invading the bone. In the rabbit which died at 89 days, the clear viscous joint fluid contained a few macrophages containing colourless inclusions but the histological appearance was normal.

The longest surviving rabbit of those dosed throughout the experiment with prednisolone died 168 days after challenge. The trace of slightly sticky 


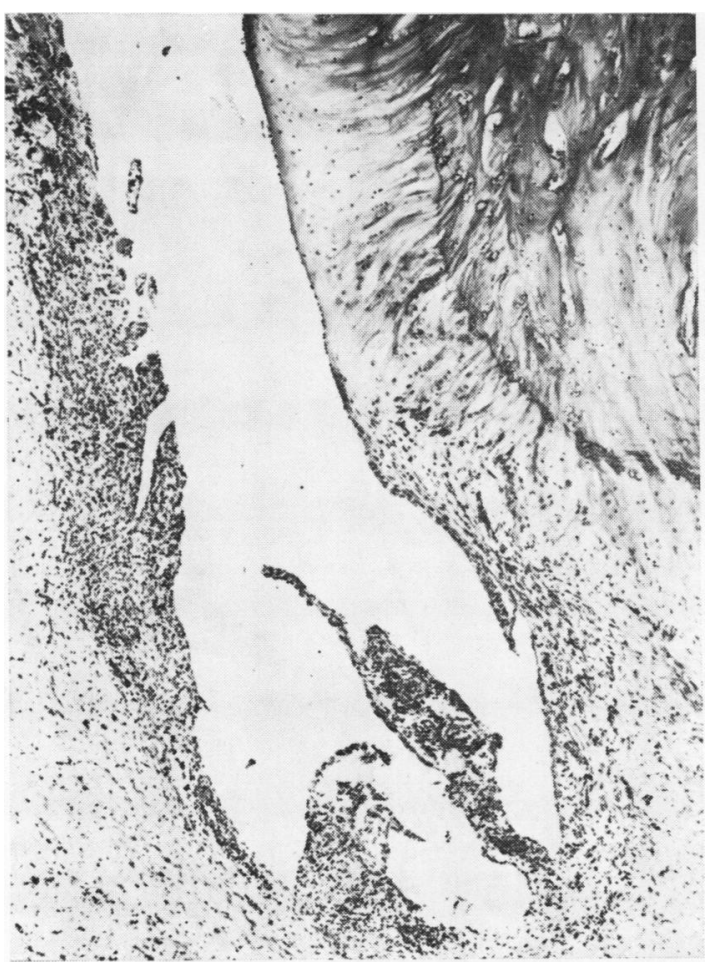

FIG. 6 Challenged right knee joint of rabbit 145 dosed daily with prednisolone from day of challenge and killed 101 days after challenge. Articular cartilage and meniscus being invaded by inflamed synovial tissue. Haematoxylin and eosin. $\times 60$

exudate contained only synovial cells. The articular cartilage was degenerated in patches and the surface was undulating (Fig. 7).

Group Ia-Rabbits dosed daily with prednisolone from the day of challenge to day 100, and killed on day 200 EXTERNAL APPEARANCE The injected knees were similar to those of the other rabbits dosed with prednisolone from the day of challenge. When dosing was stopped on the 100th day slight swellings began to develop, reached a maximum by about 130 days and then tended to decrease (Table II).

INTERNAL APPEARANCE A moderate amount of thin cloudy exudate was present in the joints, the synovial membranes were slightly proliferated but there were no erosions. There were many cells in the exudate, mostly polymorphs and small lymphocytes, and about 10 per cent. macrophages. The macrophages contained ingested polymorphs but very few colourless inclusions. The synovial tissue was increased with infiltration by fibroblasts, and lymphoid and plasma cells. Long synovial villi were present in both animals but were more developed in rabbit 143 with dense layers of lymphoid and plasma cells at the periphery. Parts of the menisci were being displaced

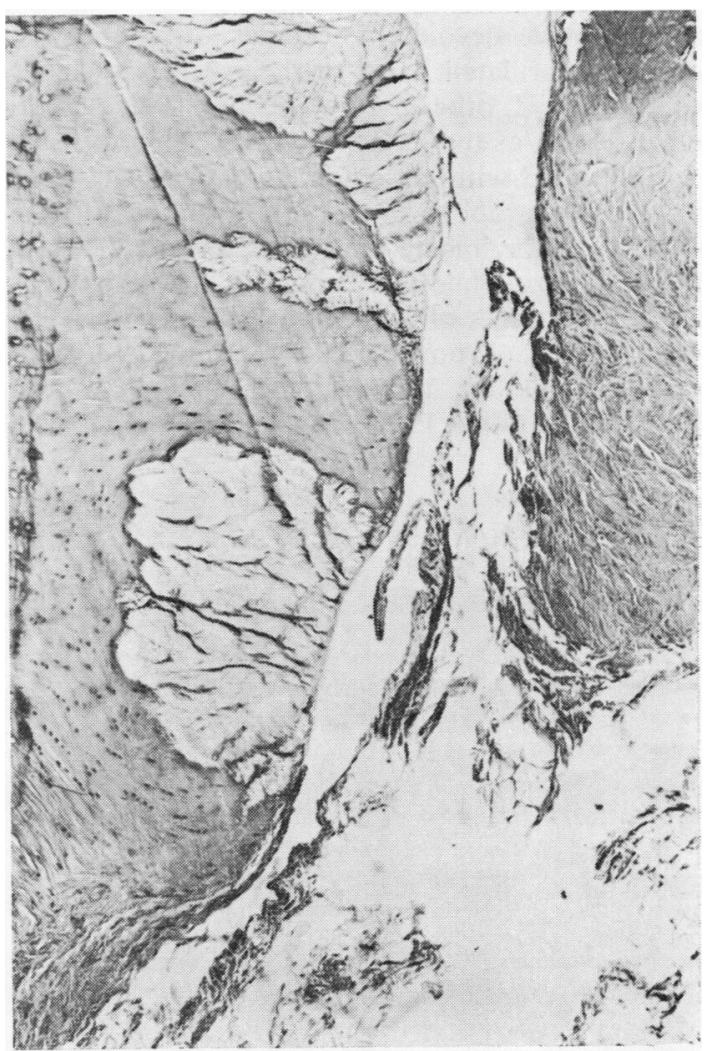

FIG. 7 Challenged right knee joint of rabbit 147 dosed daily with prednisolone from day of challenge till death 168 days after challenge. Meniscus almost normal, synovium slightly proliferated and articular cartilage degenerating in patches. Haematoxylin and eosin. $\times 63$

by fibrous tissue, but the articular cartilage was normal except for some pannus at the edges.

Group II-Rabbits dosed daily with prednisolone from the 51 st day after challenge until death

EXTERNAL APPEARANCE The swellings in the injected joints were partially reduced during the early period of dosing with prednisolone but never abolished (Table II).

INTERNAL APPEARANCE When killed 101 days after challenge rabbit 148 had only a trace of joint fluid with few cells. The synovial tissue was slightly villous and the articular cartilage was slightly fibrillated in one area with a patch of very large chondrocytes. Rabbit 149 showed a greater reaction. The thick granular joint exudate was similar to that in untreated challenged animals. The synovial tissue was greatly proliferated and vascularized with masses of irregularly-shaped villi lined with fibroblasts and round cells. Some of the villous processes appeared to contain chondrocytes and there were areas of fibrinoid deposit between the villi. The 
menisci were devoid of cellular structure and becoming fibrillated. Parts of the articular cartilage were fibrillated, other parts were completely absent, and the bone at the junction with the joint capsule was infiltrated with cartilaginous tissue. Neither of the remaining rabbits in this group survived to the end of the experiment; they died 167 and 192 days after challenge while still being dosed with prednisolone. The traces of joint fluid contained very few lymphoid and synovial cells. The menisci were normal in outline in rabbit 153 but had been obliterated in rabbit 152 by cartilaginous metaplasia (Fig. 8).

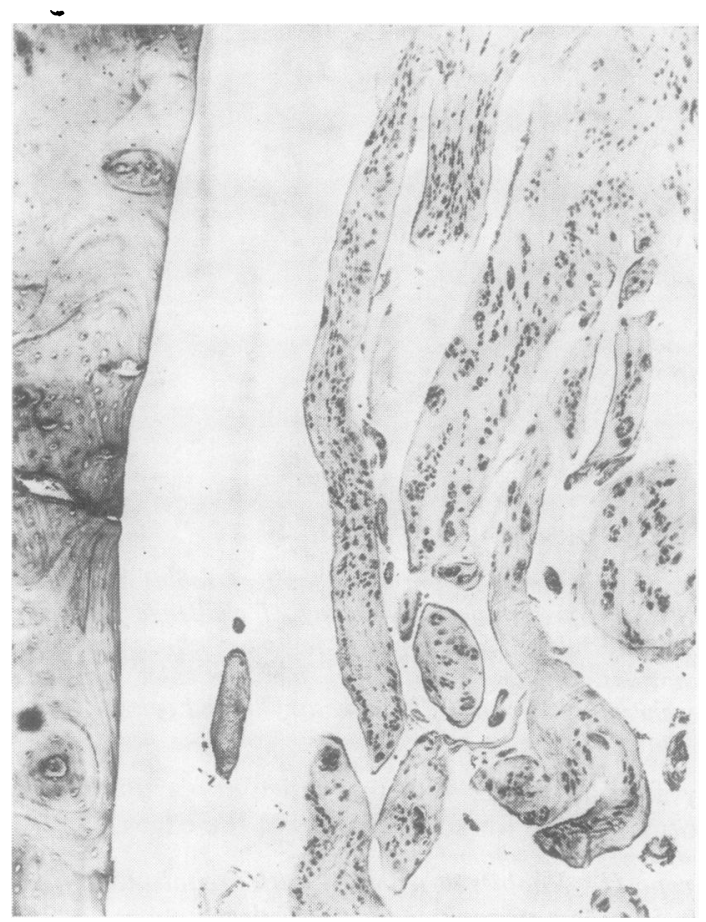

FIG. 8 Challenged right knee joint of rabbit 152 dosed daily with prednisolone from 51 days after challenge till death 167 days after challenge. Synovium on meniscus showing cartilaginous metaplasia. Articular cartilage absent. Haematoxylin and eosin. $\times 63$

The articular cartilage was absent from large areas in both animals. There was little active synovial proliferation but some cartilaginous metaplasia at the junction with the bone (Fig. 9).

Group IIa-Rabbits dosed daily with prednisolone from the 51st to the 100th day after challenge and killed on day 200

EXTERNAL APPEARANCE The injected joints developed swellings which were partially reduced during the period of dosing with prednisolone and increased when dosing was stopped (Table II).

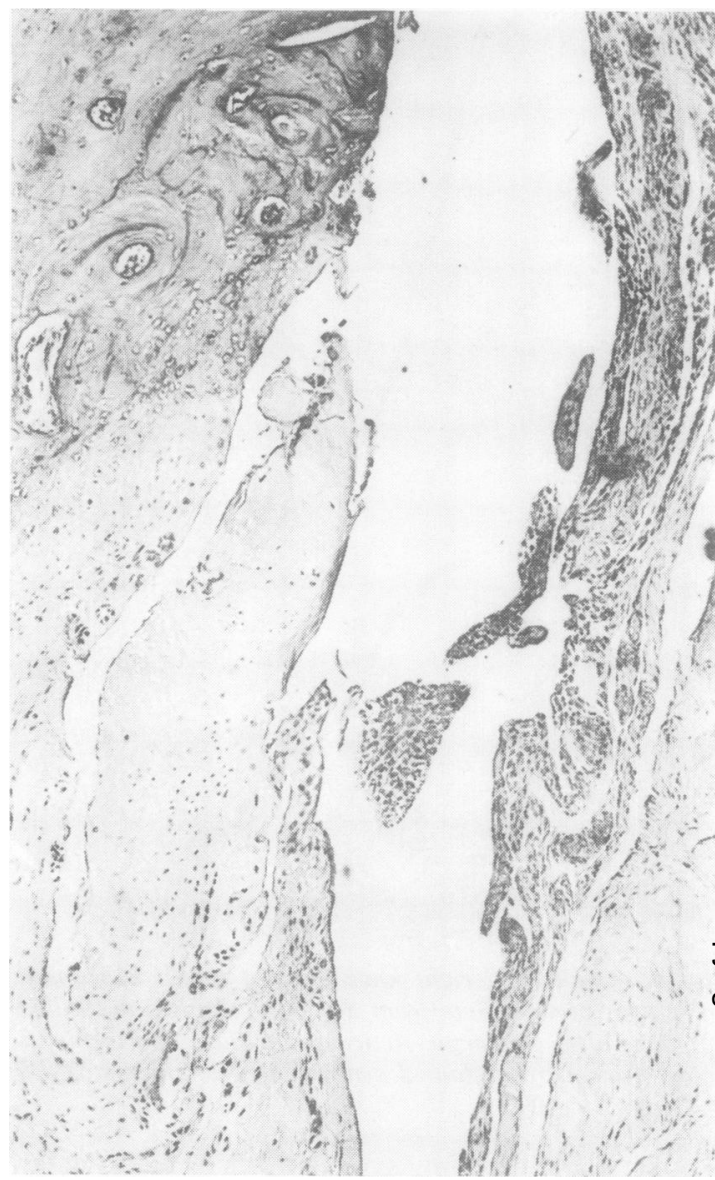

FIG. 9 Challenged right knee joint of rabbit 152 dosed daily with prednisolone from 51 days after challenge till death 167 days after challenge. Junction of articular cartilage with synovium. Little active synovial proliferation but cartilaginous metaplasia in some areas and articular cartilage absent in others. Haematoxylin and eosin. $\times 75$

INTERNAL APPEARANCE There was a moderate amount of thick cloudy exudate, the synovial membranes were greatly proliferated, and there were erosions of the femoral condyles and patellar grooves. The exudates contained masses of cells, mostly polymorphs with smaller numbers of small lymphocytes and macrophages, the latter containing ingested polymorphs and very distinct small round colourless inclusions. The synovial tissues were developed into many villi containing fibroblasts and dense foci of lymphocytes and plasma cells. A large fibrous multiple cyst-like structure, containing infiltrated exudate, was seen at the base of the synovium in rabbit 150 . The bases of the menisci of both rabbits were infiltrated with inflammatory tissue and their apices fibrillated (Fig. 10). The articular cartilage was either absent, fibrillated or being invaded by active synovial pannus (Fig. 11). 


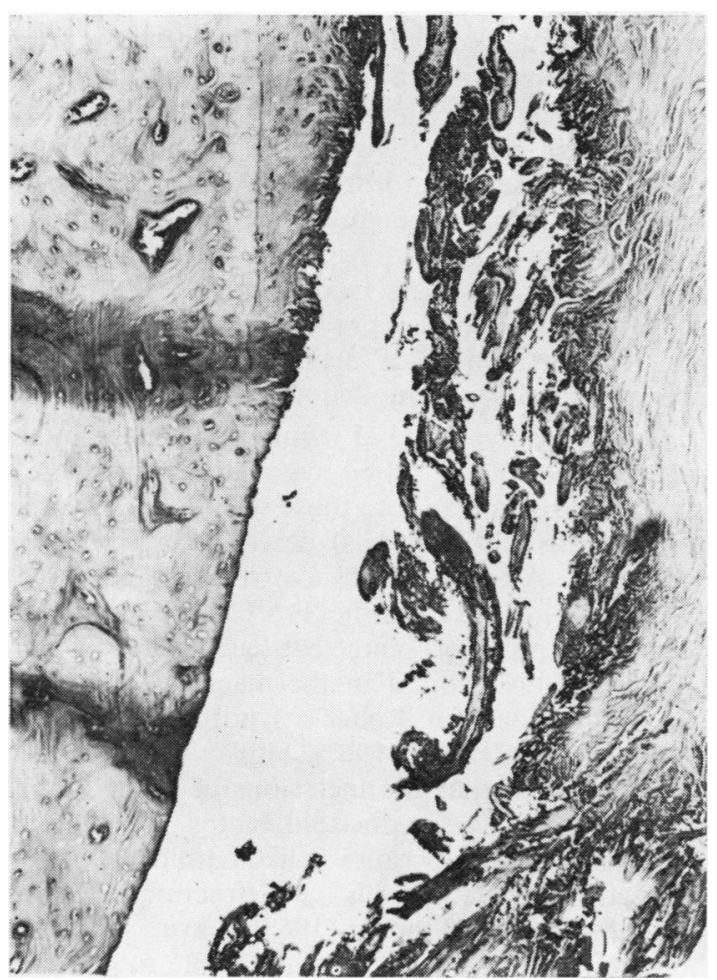

FIG. 10 Challenged right knee joint of rabbit 150 dosed daily with prednisolone from 51 to 100 days after challenge and killed 200 days after challenge. Meniscus fibrillated and interspersed with cellular exudate. Articular cartilage absent in some areas. Haematoxylin and eosin. $\times 66$

Group III-Rabbits dosed daily with prednisolone from the 101 st day after challenge till death

EXTERNAL APPEARANCE The injected joints were similar to those of the animals which did not receive prednisolone at any stage. Both rabbits died before the end of the experiment.

INTERNAL APPEARANCE The traces of synovial fluid contained only a few synovial cells. Rabbit 155 had relatively normal fatty synovial tissue with few villi, and the menisci were slightly degenerate though normal in outline. The articular cartilage was fibrillated with areas of cartilaginous metaplasia. Rabbit 154 showed a more severe reaction. The synovial tissue was heavily vascularized with fibroblastic villi interspersed with cartilaginous metaplasia infiltrating into and around the degenerating menisci. Some areas of the articular cartilage were degenerating with clumps of deeply stained chondrocytes, while other areas were greatly fibrillated or almost absent.

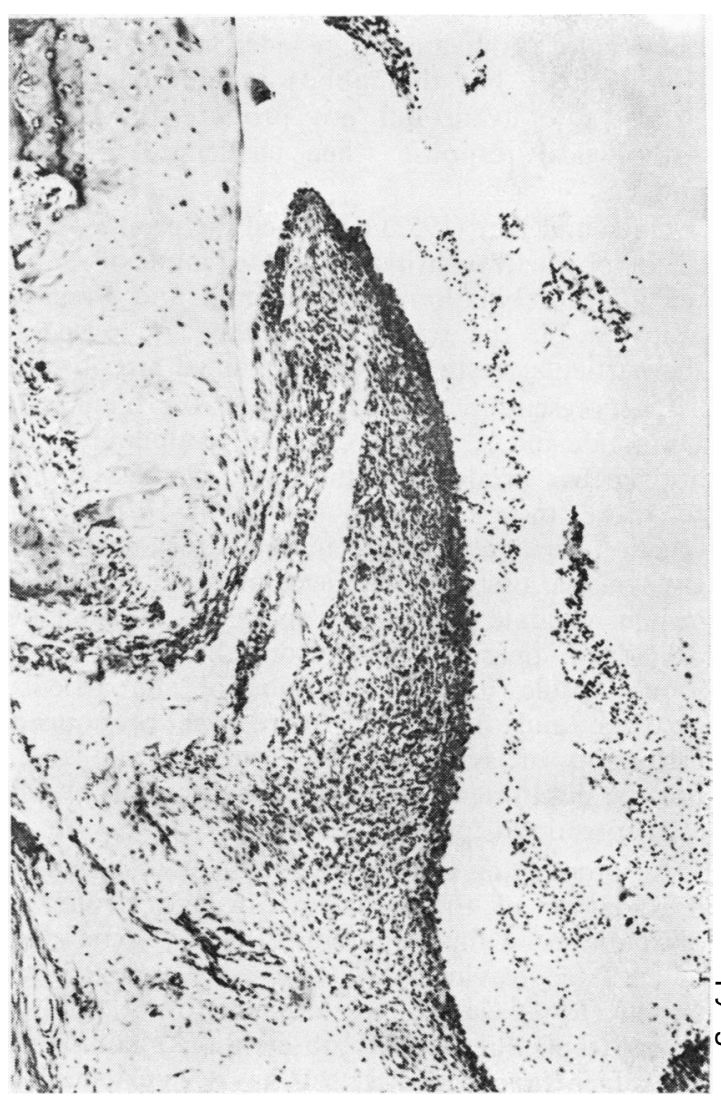

FIG. 11 Challenged right knee joint of rabbit 151 dosed daily with prednisolone from 51 to 100 days after challenge and killed 200 days after challenge. Synovial pannus spreading over articular cartilage. Haematoxylin and eosin. $\times 75$

\section{Discussion}

Experimental animal models of rheumatoid arthritis can only aim at mimicking its pathology and chronicity. Attempts over the past half century to produce such models have been reviewed by Gardner (1960) and Rubens-Duval, Villiaumey, and Kaplan (1966). It is clear that the most successful models involve, at least in part, immunological mechanisms. The widely used adjuvant-induced arthritis in the rat, first described by Stoerk, Bielinski, and Budzilovich (1954) and developed by Pearson and Wood (1959), is thought to depend on a disseminated delayed hypersensitivity reaction (Waksman, Pearson, and Sharp, 1960). It can be passively transferred by living lymphoid cells (Waksman and Wennersten, 1963), or lymph node or spleen cells (Pearson and Wood, 1964) of sensitized donors. The lesion produced in rabbits by Dumonde and Glynn (1962) involves both immediate and delayed hypersensitivity reactions. Glynn (1968) demonstrated that rabbits developed antibodies to antigen whether or 
not Freund's adjuvant was included in the immunization process, but the rabbits immunized without Freund's adjuvant did not produce the chronic pathological response when challenged with the antigen.

Odell and Key (1957) described the production of an anaphylactic arthritis in the knee joints of rabbits using a combination of ovalbumin and Freund's adjuvant, but the exact methods they employed and the particular responses they obtained are obscure.

The present model, based upon the method of Dumonde and Glynn (1962), using ovalbumin as the antigen has produced pathological changes similar to those they described for fibrin. Briefly, the reaction began as an acute inflammatory reaction of the synovial tissue with an accumulation of a highly cellular exudate in the joint space. As the response developed, pannus spread from the edges of the joint capsule into the margins of the articular cartilage and bone, and there was pronounced formation of synovial villi. The synovial tissue became infiltrated with lymphocytes and plasma cells sometimes forming dense foci.

Accompanying these changes there was a general degradation of the articular cartilage leading to fibrillation and finally complete loss of some areas of cartilage leaving bone exposed. Dumonde and Glynn (1962) claimed a chronicity of at least 16 weeks (the limit of their observations) but in the experiments recorded here this has been extended to 35 weeks and to 105 weeks with two rabbits not forming part of the present experiment.

The persistence of a joint exudate of almost constant cellular composition, one of the striking features of the reaction, may help to account for the chronicity. The intense fibrillation of the articular cartilage and menisci did not appear to be directly caused by the pannus, so that other explanations for the damage must be sought. Dingle (1962) suggested that destruction of articular cartilage is related to activation of lysosomal enzymes in cells closely apposed to the cartilage. Barland, Novikoff, and Hamerman (1964) demonstrated accumulations of large altered lysosomes containing phagocytosed material in the synovial lining cells, and high enzyme activity in the synovial fluid, in rheumatoid arthritis. They suggested that unknown events initiate processes which lead to the eventual release of enzymes which degrade the cartilage matrix. Weissmann and Spilberg (1968) showed that filterable products of leucocytes could degrade bovine nasal cartilage in vitro, and they recently extended this work in vivo by injecting granules prepared from rabbit leucocytes into the knee joints of rabbits (Weissmann, Spilberg, and Krakauer, 1969). Repeated injection led to acute inflammation, hypertrophy and hyperplasia of the synovial lining cells, pannus formation, and cartilage degradation. They suggested that escape of granule contents from lysosomes into the joint cavity was sufficient to account for proliferative and degradative changes observed in several forms of clinical and experimental arthritis. The presence in the synovial exudate of many polymorphs in various stages of degradation, and their ingestion by macrophages, suggests that a similar process may be responsible for the destruction of articular cartilage in the present experimental model.

The many small round inclusions present in the macrophages of the rabbit synovial exudate bore a superficial resemblance to those seen in the 'rheumatoid arthritis cells (RA cells)' described by Hollander, McCarty, Astorga, and Castro-Murillo (1965). Unlike the inclusions in the 'RA cell', they were not seen in the polymorphonuclear leucocytes and were similar to those found in the macrophages of the synovial exudate in Reiter's syndrome by Pekin, Malinin, and Zvaifler (1967). Hollander and others (1965) claimed that the inclusions of the 'RA cell' are complexes of 'rheumatoid factor' with altered gamma globulin, because 'rheumatoid factor' is released when the cells are fractured. Sones, McDuffie, and Hunder (1968) have suggested, however, that the 'rheumatoid factor' might have been present on the surface of the cells and did not necessarily derive from the inclusions. The exact nature, significance, and diagnostic specificity of the 'RA cell' remains uncertain (Bluhm, 1969), but they, and similar cells, are still worthy of study as they may help to explain some of the underlying processes occurring in certain chronic inflammatory conditions.

In the present experimental model, though the small inclusions and ingested polymorphs are often present in the same macrophage, they may represent different phenomena or different stages of the same phenomenon. The small inclusions could be complexes of altered tissue constituents and antibodies formed against them, or they could be a late stage in the destruction of the ingested polymorphs.

Preliminary experiments using fluorescent goat anti-rabbit immunoglobulin $G$ failed to show fluorescence in the macrophages, but the small inclusions are lipid in nature with a strong affinity for the fat stain 'fat red E7B' (Ciba-Clayton). Wyllie, Haust, and More (1966) have described lipid-containing cells in the synovium of patients with rheumatoid arthritis. They consider this lipid material to be the incompletely digested residues of lipoprotein derived from damaged cytoplasm originally taken into autophagic vacuoles. The synovial exudate macrophages in the present model could contain similar residues. The macrophages themselves may be detached synovial cells as they 
frequently appear in clumps and highly vacuolated cells are often seen on the synovial surface in the most severely reacting joints. The number of small inclusions in each macrophage increases as the reaction progresses until each cell appears to be almost bursting with them. Zucker-Franklin (1966) has suggested that rheumatoid synovial fluid contains a large amount of particulate matter which is ingested by phagocytic cells. Phagocytosis is accompanied by degranulation and release of lysosomal enzymes causing further injury. In the confined space of a joint a vicious cycle is set up leading to a chronic reaction. Weissmann (1964) among others has made a similar suggestion, and like Glynn (1968) has emphasized the possible role of an autoimmune reaction to altered tissue constituents. In the present experimental model, which is initiated by a comparatively well-understood mechanism, all the processes which have been briefly outlined above could help to account for the chronicity of the reaction. All authors proposing hypotheses to account for the chronicity of rheumatoid arthritis (Weissmann, 1964, 1967; Zvaifler, 1965; Hamerman, 1966; Glynn, 1968) stress that, though we may recognize a final common path in this type of reaction, this gives no evidence as to the initial cause.

The first study of the effects of prednisolone in this model of arthritis are only of an exploratory nature. The daily dose of prednisolone $(1 \mathrm{mg} . / \mathrm{kg}$.) was clearly too high, leading to premature deaths, and the number of animals receiving each treatment was too small.

The dose regimens were chosen to demonstrate the properties of prednisolone in two situations. In the first, prednisolone was given daily from the time of challenge, which has no clinical parallel but represents the earliest possible prophylactic use of prednisolone. In the second, dosing with prednisolone was started and sometimes stopped at various times during the development of the reaction, and was thus nearer to the clinical situation.

Knee-joint measurements suggested that treatment with prednisolone from the day of challenge (Group I) suppressed the reaction completely within a few days. This was only a superficial impression. Microscopic examination revealed evidence of a low grade of inflammatory reaction in the synovial tissue of some animals, but none of the severe villous formation or fibrillation of the cartilage seen in the untreated group. In rabbit 145, killed at 101 days, the joint was slightly swollen and contained a cellular synovial exudate similar to that seen in untreated animals. In this animal and one surviving till 168 days, the articular cartilage was degenerating (Figs 6 and 7). Several publications have described the suppression of the superficial manifestations of rat adjuvant-induced arthritis by steroids (Newbould, 1963; Ward and Cloud, 1966; Graeme, Fabry, and Sigg, 1966; Winter and Nuss, 1966), but none gives details of the effects on the pathology. It is possible that, as in this series of experiments, superficial observations give a false impression of the efficacy of a drug.

Slight swellings of the injected joints developed when prednisolone was discontinued after 100 days (Group I $a$ ) and probably reflected the moderately intense hypertrophy of the synovial lymphoid tissue. There was every indication that a severe chronic reaction was slowly developing. This confirms the impression gained from Group I that suppression of the reaction by prednisolone was neither complete nor permanent. In Groups II and III, severe joint damage had occurred in most animals before dosing with prednisolone was started 51 or 101 days after challenge. In these groups prednisolone had little effect except to reduce the number of lymphoid cells and accentuate the development of bizarre cartilaginous processes which arose from the synovial tissue, menisci, or fibrillated articular cartilage. The inflammatory reaction and joint destruction seen at 200 days in animals given prednisolone from day 51 to day 100 only (Group II $a$ ) was possibly more severe than in the untreated animals. The histological appearance gave no indication that the reaction had been arrested at any stage.

Clearly, the experimentally-produced arthritis was of an intense long-lasting nature, which was only partially suppressed by prednisolone. The initiating cause being known - the intra-articular injection of ovalbumin into a previously sensitized animal-only two broad possibilities can account for the chronicity. Either some ovalbumin or products of the initial reaction persist in the joint. Several workers have measured the persistence of foreign material injected into joints (Rodnan and MacLachlan, 1960; Glynn, 1968; Sliwiński and Zvaifler, 1969). Although traces can be detected for many weeks the amounts are very small. It is more probable that degradation products of the initial reaction, or antibodies formed against them, are responsible. Identification of the nature, source, and fate of the inclusions seen in the macrophages may help in elucidating the mechanisms involved, as they tend to be present in direct proportion to the degree of joint damage. Whatever mechanisms are responsible for the chronicity of the reaction, prednisolone does not remove them. It only causes a partial suppression of the reaction even when given in high doses from the time of challenge.

The results of these experiments, therefore, are offered to rheumatologists in the hope that they may throw some light on the role of prednisolone in the clinical condition. 


\section{Summary}

A chronic arthritis has been produced in rabbit knee joints by the intra-articular challenge with ovalbumin in animals previously sensitized with ovalbumin emulsified in Freund's complete adjuvant. The superficial and histological course of the reaction has been studied in animals given no further treatment and in those given daily oral doses of prednisolone (1 mg./kg.) at various stages of the reaction.

The reaction was biphasic. The initial swellings had subsided partially by 10 days but began to re-appear by 70 days and reached a maximum about 160 days after challenge. The reaction began as an intense synovitis with a synovial exudate containing many polymorphonuclear leucocytes, lymphocytes, and macrophages. The macrophages contained ingested polymorphs and many small lipid-like inclusions which increased in number as the reaction proceeded. The synovitis was accompanied in the later stages by destruction of the menisci and articular cartilage.

Superficial observations suggested that prednisolone given from the day of challenge suppressed the reaction. Histologically, the suppression was only partial and not permanent. The joint damage continued at a reduced rate until dosing was stopped, when the rate and degree of destruction increased.

The possible mechanisms involved in the chronicity of the reaction are discussed.

I wish to thank Miss J. M. Davies for preparing the histological sections and Mr. R. J. Hutchings for continuous personal assistance.

\section{References}

Barland, P., Novikoff, A. B., and Hamerman, D. (1964) Trans. Ass. Amer. Phycns, 77, 239 (Lysosomes in the synovial membrane in rheumatoid arthritis: A mechanism for cartilage erosion).

BLuнм, G. B. (1969) Ann. intern. Med., 71, 432 (Rheumatoid arthritis cells).

Dingle, J. T. (1962) Proc. roy. Soc. Med., 55, 109 (Aetiological factors in the collagen diseases. Lysosomal enzymes and the degradation of cartilage matrix).

Dumonde, D. C., AND GlynN, L. E. (1962) Brit. J. exp. Path., 43, 373 (The production of arthritis in rabbits by an immunological reaction to fibrin).

GARDNER, D. L. (1960) Ann. rheum. Dis., 19, 297 (The experimental production of arthritis. A review).

GLYNN, L. E. (1968) Ibid., 27, 105 (Heberden Oration, 1967. The chronicity of inflammation and its significance in rheumatoid arthritis).

Graeme, M. L., Fabry, E., and Sigg, E. B. (1966) J. Pharmacol. exp. Ther., 153, 373 (Mycobacterial adjuvant periarthritis in rodents and its modification by anti-inflammatory agents).

Hamerman, D. (1966) Amer. J. Med., 40, 1 (Editorial: New thoughts on the pathogenesis of rheumatoid arthritis).

Hollander, J. L., McCarty, D. J., Astorga, G., and Castro-Murillo, E. (1965) Ann. intern. Med., 62, 271 (Studies on the pathogenesis of rheumatoid joint inflammation. I. The 'R.A. cell' and a working hypothesis).

NewBould, B. B. (1963) Brit. J. Pharmacol., 21, 127 (Chemotherapy of arthritis induced in rats by mycobacterial adjuvant).

Odell, R. T., AND KeY, J. A. (1957) Surg. Forum, 1956, 7, 596 (The production of anaphylactic arthritis with the use of Freund's adjuvant).

Pearson, C. M., AND Wood, F. D. (1959) Arthr. and Rheum., 2, 440 (Studies of polyarthritis and other lesions induced in rats by injection of mycobacterial adjuvant. I. General clinical and pathologic characteristics and some modifying factors).

- (1964) J. exp. Med., 120, 547 (Passive transfer of adjuvant arthritis by lymph node or spleen cells).

Pekin, T. J., Malinin, T. I., AND Zvaifler, N. J. (1967) Ann. intern. Med., 66, 677 (Unusual synovial fluid findings in Reiter's syndrome).

Rodnan, G. P., AND MAClachlan, M. J. (1960) Arthr. and Rheum., 3, 152 (The absorption of serum albumin and gamma-globulin from the knee joint of man and rabbit).

Rubens-Duval, A., Villiaumey, J., And Kaplan, G. (1966) Path. et Biol., 14, 1084 (Les tentatives de reproduction expérimentale des polyarthrites rhumatismales).

SliwiNSKI, A. J., AND ZvAIfLer, N. J. (1969) Arthr. and Rheum. 12, 504 (The removal of aggregated and non aggregated autologous gamma globulin from rheumatoid joints).

SONES, D. A., MCDuffie, F. C., AND Hunder, G. G. (1968) Ibid., 11, 400 (The clinical significance of the RA cell).

Stoerk, H. C., Bielinski, T. C., AND Budzilovich, T. (1954) Amer. J. Path., 30, 616 (Chronic polyarthritis in rats injected with spleen in adjuvants).

Waksman, B. H., Pearson, C. M., AND Sharp, J. T. (1960) J. Immunol., 85, 403 (Studies of arthritis and other lesions induced in rats by injection of mycobacterial adjuvant. II. Evidence that the disease is a disseminated immunologic response to exogenous antigen).

- AND Wennersten, C. (1963) Int. Arch. Allergy, 23, 129 (Passive transfer of adjuvant arthritis in rats with living lymphoid cells of sensitised donors).

Ward, J. R., AND Cloud, R. S. (1966) J. Pharmacol. exp. Ther., 152, 116 (Comparative effect of anti-rheumatic drugs on adjuvant induced polyarthritis in rats). 
WeissmanN, G. (1964) Lancet, 2, 1373 (Lysosomes, autoimmune phenomena, and diseases of connective tissue). (1967) Ann. Rev. Med., 18, 97 (The role of lysosomes in inflammation and disease). AND SPILBERG, I. (1968) Arthr. and Rheum., 11, 162 (Breakdown of cartilage protein polysaccharides by lysosomes).

- - - AND KRAKAUER, K. (1969) Ibid., 12, 103 (Arthritis induced in rabbits by lysates of granulocyte lysosomes).

WinTER, C. A., AND Nuss, G. W. (1966) Ibid., 9, 394 (Treatment of adjuvant arthritis in rats with antiinflammatory drugs).

Wyllie, J. C., Haust, M. D., AND MoRe, R. H. (1966) Lab. Invest., 15, 519 (The fine structure of synovial lining cells in rheumatoid arthritis).

ZuCKer-FrankuIN, D. (1966) Arthr. and Rheum., 9, 24 (The phagosomes in rheumatoid synovial fluid leukocytes: A light, fluorescence, and electron microscope study).

ZvaIFLeR, N. J. (1965) Ibid., 8, 289 (A speculation on the pathogenesis of joint inflammation in rheumatoid arthritis). 